\title{
Bridging the Academic/Activist Divide: Feminist Activism and the Teaching of Global Politics
}

\author{
Catherine Eschle and Bice Maiguashca ${ }^{1}$
}

\section{Introduction}

Our starting point in this article is the widespread belief that academia and activism are separate worlds, driven by contrasting aims and imperatives and governed by different rules. Such a view is based on a series of taken-for-granted and highly problematic ontological dichotomies, including mind/body, theory/practice, reason/emotion, abstract/concrete and 'ivory tower'/ 'real world'. Perhaps most fundamentally, these serve to set up thinking and reflecting in opposition to doing or acting. Thus in both activist and academic characterisations of what it is that they do, we find the frequent assumption that academics theorise and write, while for activists 'action is the life of all and if thou dost not act, thou dost nothing'; ${ }^{2}$ academics exercise their cognitive skills, while activists are animated by passion; academics are impartial commentators on the world while activists are partisan, polemical advocates; academics work in elite institutions while activists are embedded in the everyday, 'on the streets' or at 'the grassroots'. 3

Some feminists have reproduced aspects of this dichotomous thinking in their critique of academic theorising as abstract and masculinist, juxtaposed to the concrete concerns of feminist practice. Yet it seems to us that, in the main, feminists continue to challenge the division between academia and activism and the dichotomies on which it relies. As stated by Sara Bracke, an activist with European network NextGenderation, 'the division between doing and thinking is very racialised and gendered ... and that has worked against women and ethnic minorities who are entreated to act in the name of revolutions which are thought through by white male others'. Bracke insists that 'critical theoretical work is a crucial part of political work', although 'it can never replace the other kinds of political activities we need to be doing to transform social reality'.

\footnotetext{
${ }^{1}$ We would like to thank Mireille Thornton, Anna Stavrianakis and Eric Herring for their feedback on an earlier draft of this article. Thanks are also due to the Nuffield Foundation, the British Academy and the ESRC for funding the research on which this article is based, and to the translators that helped us on location. Our biggest debt is to the interviewees whose words and practices we discuss here. They gave their time generously to us and their activities remain an inspiration.

${ }^{2}$ This phrase, originating with Gerrard Winstanley of the seventeenth-century Diggers, was emblazoned outside the eco-camp in Stirling at which protestors gathered during the G8 summit at Gleneagles, July 2005. See Shut them Down! The G8, Gleneagles 2005 and the Movement of Movements (Leeds and Brooklyn: Dissent and Autonomedia, 2005).

${ }^{3}$ For a defence of the academic/activist distinction drawing on several of these dichotomies, see Stanley Fish, 'Why we Built the Ivory Tower', New York Times 1 June 2004, online at http://frontpagemag.com/Articles/ReadArticle.asp?ID=13593. For more critical interrogations, see Lisa Yun Lee, 'Who's Afraid of Theory?', June 2004, online at http://www.inthesetimes.com/site/main/article/161/ and Lisa Featherstone et al., 'Action will be Taken: Left Anti-Intellectualism and its Discontents', online at http://www.lipmagazine.org/articles/featfeatherstone activistismp.shtml.

${ }^{4}$ Interview, Dublin, 12/7/04.
} 
In the process of undertaking 'critical theoretical work', feminists have rethought what knowledge is and who can be knowers. They have problematised the masculinist reliance on 'objectivity' in academic thought, and the associated privileging of mind over body and reason over emotion, pointing instead to ways knowledge can be generated from women's lives, from the 'everyday' and from within the feminist movement. Moreover, they have sought to re-conceptualise what politics is and who can be a political subject, criticising reductive accounts of citizenship and activism, expanding politics into the private, and offering an embodied, relational conception of agency. At the more practical level, feminists have established their own sites of knowledge production that aim to bridge the gap between universities and the feminist movement, ranging from consciousness-raising groups to autonomous women's colleges, and from women's libraries to women's studies and latterly gender studies programmes in universities. The creation of and participation in such programmes has meant that, notwithstanding undoubted problems of institutionalisation, the university has become a crucial source of politicisation and site of political activism for many feminists.

As two feminists working in British universities, we agree that the divide between academia and activism is problematic and should be challenged. One way in which we seek to do so in our own work is through what could be called 'politicised' or 'critical scholarship', that is, research that explicitly recognises and takes responsibility for its normative orientation; that aims to empower a marginalised and oppressed constituency by making them visible and audible; and that attempts to challenge prevailing power hierarchies, including in terms of the construction of knowledge. While all research is political in the sense that it has a relationship to power, 'critical scholarship' is openly driven by political commitment and aligns itself with broader struggles for social change. More concretely, our current research project seeks to develop a situated mapping of the history, structure, ideologies and practices of feminist 'anti-globalisation' activism. ${ }^{5}$ In so doing, we hope to challenge the marginalisation of feminism in the theory and practice of the 'anti-globalisation' or 'global justice' movement and to open up new lines of enquiry into the nature of power and resistance in a globalised world. Our fieldwork for this project has centred on the World Social Forum process and has taken us to two European Social Forums (in Paris, November 2003, and London, October 2004) and two World Social Forums (in Mumbai, January 2004, and Porto Alegre, January 2005). At each site we used participant observation techniques, gathered activist documentation and conducted semi-structured interviews with women and some men we identified as feminist. We also conducted supplementary interviews in each country before or after the event.

Turning to our teaching, we have made some attempt to develop a 'critical pedagogy' that aligns with the goals of our 'critical scholarship'. Most obviously, we have brought social movements into the curriculum as an object of study and thereby

\footnotetext{
${ }^{5}$ We acknowledge that the label of 'anti-globalisation' is rejected by many activists; indeed some find it wholly objectionable although many still use it strategically. Different names have emerged in different contexts, including 'critical globalisation', 'alternative globalisation' and 'global justice'. We also note that the label of 'feminist' is problematic for some of our interviewees, particularly those in India. So it should be stressed that 'feminist "anti-globalisation" activism' is our short-hand for activism which combines opposition to gender-based oppression or inequality with a critique of the unaccountable power of corporations, financial institutions and Western states; the neoliberal trade policies that foster it; and its economic, social and environmental consequences.
} 
sought to expand the remit of our discipline of International Relations (IR). In addition, we have tried to encourage our students to reflect on the conceptual implications of centring social movements as key actors in global politics. What we have not done thus far is to explore in what ways social movements can be a source of critical pedagogy. In other words, what can we learn from activism about what and how we teach on our courses on global politics?

In what follows, we seek to answer this question by exploring the educational practices and self-understandings of the feminist 'anti-globalisation' activists we encountered during our fieldwork. ${ }^{6} \mathrm{We}$ argue that those of us in academia engaging in 'critical' scholarship and pedagogy can gain considerable insight and inspiration from activism as we seek to redraw the boundaries of our subject matter and engage our students. While we do not suggest that a complete collapse of the distinction between activism and academia is possible or even desirable, we do claim that building bridges such as this one across the divide can radicalise and reinvigorate academic practice.

The article is divided into three parts. We begin with a consideration of our current teaching, pointing to some of the ways we have sought to institute a 'critical pedagogy' and to the limitations of our efforts. Secondly, we turn to the ideas and practices of feminist 'anti-globalisation' activists before, finally, developing some tentative suggestions for how these could be integrated into our own classes.

\section{I: Being Disciplined: Aspirations and Frustrations in the Teaching of Global Politics}

We begin the discussion of our teaching by reflecting on the distinctive aims and mores of academic education. Its key objectives, at least in the social sciences, are to teach students about an established body of literature (the academic canon) and the world 'out there'. In terms of both, we are required to disseminate the knowledge that has been produced and ratified by a community of scholars. In this way, we reproduce and reinforce the parameters of our disciplines as well as the criteria by which we define knowledge in those disciplines in the first place. In addition, students are expected to develop the capacity for critical reflection and to generate their own questions about and perspectives on the established literature. To put it another way, university education seeks to enable students to become subjects or producers of knowledge. Indeed, this dimension of learning, along with the development of a range of skills or 'competencies', centring on reading, writing and verbal communication, are seen increasingly as the fundamental imperatives of university education. ${ }^{7}$ They are reinforced by an academic ethos that fosters learning as an individualised enterprise and that values and protects pluralism and freedom of thought.

\footnotetext{
${ }^{6}$ Thus we do not offer a review of pedagogical literature produced by academic feminists, though many of their arguments resonate with those made here; see, for example, Penny Welch, 'Is a Feminist Pedagogy Possible?' in Changing the Subject: Women in Higher Education, eds. Jocey Quin et al. (London: Taylor and Francis, 1994), 149-162, and Berenice Malka Fisher, No Angel in the Classroom: Teaching Through Feminist Discourse (Lanham, MD: Rowman and Littlefield, 2000).

7 See, for example, Robert Pithers and Rebecca Soden, 'Critical Thinking in Education: A Review', Educational Research, 42, no. 3 (2000): 237-49; also John Cowan, On Becoming an Innovative University Teacher: Reflection in Action (Buckingham: Open University Press, 1998), Chap.3.
} 
While we agree with the main thrust of this mandate, our commitment to 'critical' scholarship and pedagogy has pushed us to modify some aspects of it. Below we consider some important issues and dilemmas in terms of teaching global politics, with regard to the substance of our courses, the methods by which we teach and our own role as 'teachers'.

With regards to what we teach, the substantive content of our courses on global politics remains defined by two central features. First, in terms of delivering knowledge about the world 'out there', we have sought to counter reductionist understandings of global politics as either 'current affairs', as some of our students would have it, or the 'high politics' of interstate relations, as some our colleagues would prefer, by offering what could be characterised as 'IR-plus'. Thus, in addition to teaching our students about war, international regimes and transnational corporations, we also introduce them to core-periphery relations as defined by dependency theory, decolonisation, revolutionary movements, the politics of famine, and protests in India against World Bank projects. However, we are increasingly aware that this is an 'add and stir' approach, functioning to leave the core of the discipline intact. ${ }^{8}$ What is more, a fairly restrictive understanding of global politics is still at work here, in terms of focusing attention on governing institutions and/or global power structures. We frequently send our students to look on high or in far away places for global politics, with the result that our subject matter may seem removed from their everyday lives.

The second substantive dimension of our global politics courses is, of course, the IR canon. Wishing to challenge the narrowness of IR self-conceptions and expand the range of authoritative voices, we have included texts on our introductory readings lists by academics as diverse as Vandana Shiva, Peter Singer and Nira Yuval-Davis. We have been able to expand this further in our advanced classes by constructing our reading lists eclectically from IR, sociology, politics and philosophy. Perhaps more importantly, we have attempted to problematise the very notion of a canon, to show that it is not transcendental, but historically situated and politically weighted. Thus Catherine begins her introductory course with historiography, asking students to imagine what those from outside the canon and from different parts of the world would include as key events in world history, while Bice's introductory course provides a mapping of the social and political context in which competing IR 'paradigms' emerged and gained validation. Nonetheless, on reflection it is clear that our 'add and stir' approach means the canon is still positioned as the centre of the discipline, albeit in need of supplementation, explanation and elaboration. Indeed, while students may realise to some extent that the canon is constructed and contested, it is our experience that most continue to reproduce our situated mappings of that canon as uncontested fact.

This brings us to the methods of teaching we employ. Evidently, both of us are still tied, particularly in our introductory classes, to what has been widely criticised in the academic pedagogical literature as the 'transmission' model of teaching and learning, in which the lecturer, conceived as the authoritative source of knowledge, delivers

\footnotetext{
${ }^{8}$ Feminists have long made this criticism with regard to adding on women or gender to courses that remain otherwise unchanged. See, e.g., Laura Shepherd and Christina Rowlands, 'The Week on Gender: Feminists Teaching IR', paper presented at The Space Between: Theorising Gender in IR and IPE, 1-2 June 2006, University of Bristol.
} 
information to the student, conceived as a passive, empty vessel. ${ }^{9}$ Constrained by university protocol as well as large student numbers, both our introductory classes rely heavily on the lecture format, supported by textbooks and supplementary tutorials taught by postgraduates. Well aware of the pedagogical problems with this model in terms of student passivity and 'shallow learning', ${ }^{10}$ we have attempted to disrupt its logic with quizzes, 'buzz groups', student presentations and the like. While these techniques hopefully mean a livelier experience for the students, we would argue that they remain inadequate. However inspiring and pedagogically progressive a lecture series and accompanying textbook may be, taken together, they reinforce student expectations that they are receiving, and should reproduce, authoritative knowledge of the field.

Teaching advanced students in smaller, seminar-based groups has allowed us to develop more fully the 'active' and 'deep' model of learning urged in academic pedagogical literature and to experiment with different pedagogical techniques. At this level, we eschew textbooks in favour of a much wider range of reading and the facilitation of student interaction and dialogue. This dialogue, however, is largely shaped by an adversarial approach to knowledge generation - we set up formal debates, encourage the formulation of counter-arguments to established positions, and play the role of 'devil's advocate' in order to ensure that all views get a fair hearing. We have assumed, with Mariya Omelicheva, that argumentation as a cognitive process nurtures 'critical thinking' which in turn develops 'the ability to think clearly, logically and consistently, ... ability to reason without bias and prejudice, a controlled scepticism about other's beliefs, a commitment to open-mindedness, empathy for others' positions, appreciation of an interest in looking at the world from multiple perspectives and openness to self-criticism'. ${ }^{11}$ Yet we suspect that adversarial debate may not be the best vehicle for encouraging at least two of these capacities, namely empathy and 'self-criticism'. In fact, we have both become increasingly interested in exploring other, more cooperative ways to encourage critical thinking in the seminar format.

More generally, we would like to raise a point here about the overwhelming privileging of textually-based knowledge in academia, including in our own courses. Whether it takes the form of seminars or lectures, our current teaching methods buy into a near-exclusive focus on the cognitive, reasoning dimension of learning and on reading and writing skills in terms of what is judged to be a valid source of knowledge, how it is transmitted and how students are assessed on their understanding of it. While verbal communication skills are also deployed and fostered, whether by example in lectures or through participation in seminars, they seem to be seen as less important than the capacity to translate what is spoken into written text. We believe this emphasis on the text to be highly reductive and have taken steps to undermine or supplement it. For example, we have instituted rewards

\footnotetext{
${ }^{9}$ See, for example. Paul Ramsden, Learning to Teach in Higher Education (London: Routledge 1992), Chapters 2 and 7.

${ }^{10}$ Passive and shallow or surface learning is widely and unfavourably contrasted to active and deep or higher level learning in the pedagogical literature, see, for example, Ramsden, Learning to Teach, Chap. 4; Michael Prosser and Keith Trigwell, Understanding Learning and Teaching: The Experience in Higher Education (Buckingham: Open University Press, 2002), Chapter 2.

${ }^{11}$ Mariya Y. Omelicheva, 'Global Politics on Trial: Using Educational Debate for Teaching Controversies of World Affairs,' International Studies Perspectives 7, no. 2 (2006): 178.
} 
for student discussion and presentation in seminars, although in Catherine's case presentations have not been incorporated into formal, final-year assessment because of the requirement that all such work be open to verification by an external examiner. Furthermore, Bice has incorporated film and news clips as sources of information in lectures. However, it is difficult to escape the fact that students respond to and analyse these visual narratives as texts, and that they must ultimately express their analyses in written assignments.

We would like to end this part of our discussion by briefly reflecting on our own role as educators or teachers. It seems to us that there are three possible ways of thinking about this role. The first, and most problematic, is to see ourselves as 'lecturers': transmitters of knowledge to students, who are likely to give our perspectives and views the status of facts. The second, sharply contrasting, approach is to see ourselves as 'facilitators', in which we do not present our views but instead provide the space, resources and structure for students to make their own knowledge. ${ }^{12}$ In addition, we suggest a third way of thinking about our role, as 'umpires', seeking to bring competing perspectives into dialogue. This is perhaps particularly relevant in terms of the adversarial moment described above, at which point our role is to arbitrate between student knowledge claims. Although we think the latter two approaches are useful and have adopted them in seminars, we want to raise the possibility that they remain insufficient. They rightly retreat from the conception of the teacher as deliverer of facts but at the cost of evacuating any sense of the teacher's own situated knowledge and political commitments. One rationale for such agnosticism is a concern to protect the freedom of thought of students. As feminists, however, we have struggled with this expectation of impartiality and sought also to accommodate the contrasting feminist imperative to be open and reflexive. Thus in seminars we have come clean about who we are and where we come from, albeit on a somewhat ad hoc and strategic basis. The question for us remains of how to facilitate critical, meaningful dialogue among students without denying or abusing our power, or erasing our own views.

In sum, our review of our past teaching practices has shown that we have tended to supplement rather than challenge existing academic orthodoxy. We need to do more to develop a 'critical pedagogy' that fosters a broad conception of global politics, draws on a wide range of sources and innovative teaching techniques, and, crucially, encourages students themselves to become producers of knowledge in their own right. To this end, we now explore what we can learn about teaching from our research into feminist 'anti-globalisation' activism. We look in turn at the purpose and mores of activist education, the substance of what feminist activists teach, and the methods through which they teach it, elaborating on the shared and distinguishing features of the latter before considering what can be gleaned about the role of the 'teacher'.

\section{II: Feminist ‘Anti-Globalisation’ Activism and Education}

In what ways do the educational aims and ethos of feminist 'anti-globalisation' activists differ from those of academic education? Our research suggests several features of what could be called 'activist education' - most of which, we would

\footnotetext{
${ }^{12}$ The 'facilitative teacher' is contrasted favourably to the 'authoritarian' or 'instructional' model of teaching in Cowan, On Becoming an Innovative University Teacher, op. cit., p.48
} 
surmise, are not unique to feminism but typical of movement outreach more generally. Most fundamentally, activist education is about empowerment. We recognise this is a contested, problematic term in feminist and other activist circles, but think it useful in indicating at least two things. On the one hand, activist education, like university education, seeks to enable women and men to validate and develop their knowledge about the world - to become subjects or producers of knowledge. On the other hand, it seeks to enable them to act as political agents and transform that world. As Lucia Xavier of black Brazilian feminist group Criola asserts, their 'feminist' and 'anti-racist pedagogy' aims to help women 'build tools and skills so they can empower themselves'; this is combined with 'political action more at the macro-level, to show Brazilian society how it can change and fight racism and other kinds of oppression'. ${ }^{13}$ To put this another way, activist education aims to allow learners to become subjects or agents of politics. A further aspect of activist education is that it is usually strategic or goal-orientated, by which we mean that the empowerment process is targeted to particular, achievable ends. The final feature we want to highlight is that activist education seeks to build consensus around collectively generated knowledge claims and, through this, a sense of solidarity. In this way, activist education is a collective rather than individual enterprise. It is also driven by an ethos that is political: it is not agnostic or neutral about the power relations analysed but committed to challenging them.

Given this general purpose and ethos of activist education, what is it, more concretely, that feminist activists teach? What is the substantive content of feminist activist education? First and foremost, it focuses on gendered power relations. In other words, it identifies gender as one key hierarchy, among others, that shapes men and women's lives in oppressive ways that need to be resisted. Second, it seeks to impart the skills and resources to enable that resistance. Both are illustrated in the following description of a workshop by Monica Maher, who has participated in education activities with both Catolicas por el Derecho de Decider [Catholics for the Right to Decide] in Mexico and the international Grail movement of Catholic women:

The point was to look at the forces of globalisation at the grassroots level on women's lives ... that is, where gender fits in. So women spoke about these forces ... war, poverty ... militarism ... rape as a weapon of war ... it was like an analysis and then what do we do in response? ... [What is] women's creativity, women's potential and strength in response to this? ${ }^{14}$

We want to stress that the analyses of gendered hierarchies and the strategies identified for change are likely to take very different forms in different contexts. Nonetheless, we suggest that at the most general level these two things bring continuity to diverse feminist practices such as training of police officers, basic literacy work with poor women, 'capacity building' within activist groups, and selfesteem workshops.

Third, feminist activist education gathers and disseminates marginalised women's and feminist voices. In effect, feminists are seeking to reconstitute knowledge about gendered power relations in a more democratic way and to broaden women's access

\footnotetext{
${ }^{13}$ Interview, Rio de Janeiro, 12/1/05 (translation).

${ }^{14}$ Interview, Porto Alegre, 29/1/05.
} 
to that knowledge. This can be seen, for example, in the efforts of Indian feminist NGO 'Asmita' to uncover forgotten poetry and stories from long-dead women writers who challenged gender hierarchies, and to offer support to contemporary women 'who are facing a lot of venom from male writers' because of their focus on intimate issues of sexuality, child birth and the like. ${ }^{15}$ Another example is the Indian feminist NGO 'Akshara', which describes itself as 'a women's resource centre and which believes in the power of the word, in the right to information and in its use as a tool for the transformation of individuals and society'. ${ }^{16}$ Concretely, this has meant producing low-cost pamphlets that communicate key issues and campaigns of the women's movement, and setting up a library. ${ }^{17}$

Turning now to how these groups teach, that is, the methods they deploy, we want to draw attention to two feminist events we attended at the Mumbai World Social Forum in January 2004. The first was a workshop run by the National Federation of Indian Women (NFIW) on violence, which opened with a series of shocking testimonials from young women. A woman with a savagely burned face told us she had been thrown on the fire by her husband in front of their child; several others spoke of their rescue from abusive marriages or prostitution; one very young woman, holding a baby on her hip, spoke in a barely audible whisper of her involvement in prostitution since she was a child. Following these personal stories was an animated theatrical performance about the communal massacres in Gujarat from a woman introduced as a 'street poet'. Amarjeet Kaur, the president of NFIW, closed the session with a long, declamatory speech explaining the reasons for violence in a globalised India to a spellbound audience. A second noteworthy event was the high-profile 'conference' on women and war, attended by tens of thousands of people, at which the writer and activist Arundhati Roy (among others) spoke against the US war in Afghanistan and on the Gujarat massacres. Her voice was startlingly quiet but breaking with emotion as she recounted her personal shock and anger at events. Closing early, Roy donated most of her allocated time to Gayatri, a young woman who had been raped by the Indian police and who begged the crowd to write letters to those in authority in her case. As the night drew in, we listened to chants of 'From Patriarchy! From all Hierarchy!' and to thousands singing a song for peace.

Our interviews in India revealed other, diverse educational methods among feminist NGOs. For instance, Kalpana Kannabiran of Asmita talked about the extensive use of songs, hand-painted posters and story-telling in their outreach work with rural women. ${ }^{18}$ Nandita Shah of Akshara shared with us a number of games they had devised to teach young people about gender relations and women's rights. As she enthusiastically explained:

It's snakes and ladders, you know, the game we play as children? We made it into a ladder of a woman's life and you actually play it as a game ... There are things that take you up and things that bring you down - marriage and caste

\footnotetext{
${ }^{15}$ Interview with Kalpana Kannabiran, Hyderabad, 10/1/04.

${ }^{16}$ From undated flyer titled 'Akshara' picked up at Feminist Dialogues, Porto Alegre, January 2005.

${ }^{17}$ Ibid.; 'Akshara: an NGO's profile', online at

http://www.naaritoday.com/womensnetwork/ngos/akshara.html; and the entry for Akshara on 'NGOs in India (Women)', online at http://www.indianchild.com/women_ngos_in_india.htm (both accessed $15 / 6 / 05)$.

${ }^{18}$ Interview, Hyderabad, 10/1/04.
} 
and what kind of support [you have] and whether you can make decisions about what you want to do, whether you work or not, sexual division of labour, all is there. And then you actually have a dialogue and it's amazing, it's really fantastic ... Every game is followed by discussion. ${ }^{19}$

A. Padma of Andhra Pradesh Mahila Samatha Society confirmed that 'posters, banners, audio/visual materials, as well as games' were central to their educational practice:

Another game is making them hold their hands and we ask them to come out without ... breaking the chain ... When a person wants to come out there is lot of resistance, lot of turbulence, because they have to break these hands, which are very strong, they have to see somewhere the gap and then they come out of there. So this is how we try to make the group think and analyse difficult issues of patriarchy, societal practices and power relations. $^{20}$

Our Brazilian interviewees provided us with more examples of innovative educational methods, particularly with regard to women's self-esteem workshops. Nalu Faria of SOF (Sempreviva Organização Feminista) in São Paulo described how:

starting from the experience that the women have and from what they know, we go forward. To do that we use ... games through which the women can represent their knowledge ... We use collages a lot, we bring lots of magazines so women can cut them up ... We also work with the body, with massage, with self-massage, relaxation, stretching. One method that the women's movement in Brazil used to apply a lot in workshops was the life line, the life history. We adapted this life line [technique] to a shorter period of time where we make the woman think and do a parallel between what it is to be a woman and what it is to be a man, what is the role of the women in the family, so they can see both and compare ... [There is also] a game with clay. Each person models her own body with her eyes closed. ${ }^{21}$

Reviewing these diverse educational methods, it seems to us that one common and distinctive dimension is that knowledge is generated from concrete, lived experiences. To repeat Nalu Faria, they start from the experiences women have and from what they know. Another interviewee, Nancy Burrows of the World March of Women international secretariat in Quebec, elaborated further:

there is something about the pedagogy of feminism ... that becomes so much more human ... when you start from your experiences there is no right or wrong, I can't tell you your experience is wrong. I can't tell you, you didn't feel what you were telling me you were feeling. You have to listen in order to get into the debate. ${ }^{22}$

\footnotetext{
${ }^{19}$ Interview, Paris, 14/09/03.

${ }^{20}$ Interview, Hyderabad, 8/1/04.

${ }^{21}$ Interview, São Paulo, 17/1/05 (translation).

${ }^{22}$ Interview, Paris, 14/09/03.
} 
In addition to grounding knowledge in experience, the examples above make it clear that feminist educational methods foreground emotions and the body. It is particularly evident that testimonials allow individuals to express their bodily experiences and their pain as forms of knowledge and have them validated by an audience. Moreover, emotions and the body are also very important for feminists in the transmission of knowledge. No dull lectures here, but rather passionate speakers, vibrant theatrical performances and enraptured or enraged audiences. Finally, creating space for emotions is one way feminists seek to foster empathetic identification. As Nancy Burrows suggested above, listening to testimonials involves a more 'human' interaction than reading a text, it necessitates a non-judgemental openness to the experience and feelings of others.

It is important to stress that while feminist educators start from individual experiences and emotions, they do not end there. Many of our interviewees argued for an analysis that systematises and makes sense of diverse narratives. As Nancy Burrows put it, 'we need to move past sharing stories to a common analysis ... one of the strengths I think of feminism is going from the personal reality and then ... building solidarity and building shared analysis as well'. ${ }^{23}$ This involves recognition that knowledge is shared and constructed through a process of collaboration, and insistence on the need to identify commonalities as well as differences in experiences in order to link them to overarching power structures and relations. In this context, we note that, whether feminist educational practices involve game playing or emotional testimonials, they are intended to generate dialogue and debate. Moreover, although we witnessed several adversarial confrontations at feminist events, we also want to highlight their efforts at consensus-building through dialogue. On this point, feminist research and advocacy group DAWN (Development Alternatives with Women for a New Era) provides one interesting example of how a dialogue-based method of knowledge production can be systematised and implemented. As Peggy Antrobus of DAWN told us:

The way in which the analysis evolves is that we start with an outline developed by the research coordinator ... women look at that outline and critique it in terms of their own experience, their own region. At the end of all those regional workshops we have an interregional workshop. And it's out of that interregional workshop that the final analysis comes. ${ }^{24}$

Another striking feature of feminist methods of education is that they are multimedia, going beyond a reliance on the written text to deploy imagery, song, music, theatrical performance, sculpture and so on. When we asked Nalu Faria if this use of nontextual forms of information was a response to illiteracy among the women they were teaching, she explained to us that this was only part of the story:

We don't want to use only verbal language. Many times, people draw [or sculpt or enact] something that they would not speak. We don't want to repeat dichotomies like rational/emotional, objective/subjective. We want to break with ... traditional education. ${ }^{25}$

\footnotetext{
${ }^{23}$ Ibid.

${ }^{24}$ Interview, Dublin, 10/7/04.

${ }^{25}$ Interview, São Paulo, 17/1/05 (translation).
} 
This is echoed in Monica Maher's claim that the methodology of Grail groups rejects the 'dualism of mind/body', instead 'incorporating the whole body, the spirit and the mind' ${ }^{26}$ In other words, the use of multiple media in feminist teaching methods reflects a holistic view of the learner as not simply a rational/cognitive processor of information, but a thinking, feeling, intuitive, socially embedded and spiritual being with visual, auditory and tactile sensibilities.

One final aspect of feminist practice that interests us is the way activist educators handle their role as teachers. While our field research provided us with only a limited view, what we can say with some assurance is that the neutral 'umpire' trope of academia was markedly absent. All the feminist educators that we saw in action, whether they were facilitators of dialogue or more directive transmitters of an analysis, were committed to a political point of view and made that commitment explicit. Moreover, in our opinion, the fact that feminist education seeks to empower women as knowing, political subjects militates against the production of a teacherstudent hierarchy. For the most part, feminist educators are not striving to fill empty vessels; rather they seek to facilitate and to participate in a collective process of knowledge production in the community to which they belong.

\section{Learning from Activism: Rethinking Our Teaching}

So what lessons can we draw from feminist 'anti-globalisation' activism in terms of what we teach, how we teach it and our own role as teachers?

Beginning with the contours of our subject matter, it seems to us that we need to move beyond our past approach of 'adding and stirring' additional issues, actors and voices into an IR cauldron by instead considering very different entry points into the 'real world', or the 'world out there'. One lesson that can be drawn from feminist activist education is that a more expansive conception of what constitutes 'politics' is not only possible, but vitally necessary. Most obviously, attention is focused on the importance of gender as one seminal power relation and thus teaching IR requires us, among other things, to locate gendered forms of oppression wherever they are manifest and to connect them to other, overlapping power relations which sustain them and which they reinforce. In addition, the holistic conception of the activist and learner underpinning feminist activist education indicates that we need to develop a more complex, social conception of political agency or subjectivity. If we wish in IR to go beyond tracing governance structures to understanding why and how they are being challenged and transformed, then we need to pay attention to the motivations, perceptions, feelings, life-experiences and emotional make-up of individuals and groups. All in all, then, a feminist framing of the 'real world' would mean a curriculum quite different from that which we currently teach.

A further lesson here concerns the need to rethink the geographical metaphors that we use to structure our discussions of global politics. We tend to ask our students to look outward and upward, to foreign policy and events abroad, to find such politics. And yet, as illustrated by Akshara's game of snakes and ladders or the testimonies about violence that we heard at the NFIW workshop, feminist activist education points to the fact that power and resistance unfold in context-specific, concrete and embodied

\footnotetext{
${ }^{26}$ Interview, Porto Alegre 29/1/05.
} 
ways. An alternative starting point to locating global politics and marking its boundaries, therefore, would be to get students to choose a particular practice/event of close proximity and interest to them and to ask them to unravel the conjuncture of global power relations that sustain it. More concretely, this could involve requiring students to identify one university practice or policy that angers and disempowers them as learners; to reflect on how this policy is rooted in contingent as well as multilevel structural power relations; and to formulate strategies to challenge its more negative effects. Not only should such an exercise help bring global politics 'home', but it should also demonstrate for students the utility of starting to develop knowledge of global politics from their own lives and experiences.

With respect to decentring the canon, the emphasis in feminist educational activism on the gathering and dissemination of marginal voices suggests that we need to include written and spoken sources from a wider range of lives and experiences, encompassing not only the dissidents of the discipline but also non-academics, activists and 'ordinary' people. These could be treated on reading lists and in lectures in a non-hierarchical way as equivalent sources of knowledge, albeit with close attention paid to the context from which they emerged and the type and status of knowledge claim being made. It would be very important when teaching with such a range of materials to make explicit the reasoning behind their selection, as we would no longer be able to lean on the canon and its axiomatic authority for justification. Making our criteria for knowledge explicit should prompt students to think about theirs and to locate their own sources accordingly.

Indeed, we suggest that an additional step that would further open up 'the real world' and decentre the canon would be to leave some space in the curriculum for students to choose the topics and sources that they study. Feminist activist education, as Nalu Faria emphasised, generates its precise focus and priorities from learners in a specific context, rather than imposing a pre-made template. At the time of writing we are both designing new, advanced classes on similar themes: a third year option for Bice called 'Globalisation and the Politics of Resistance' and a masters class for Catherine entitled 'Contesting Global Governance'. Thus we have an opportunity to make room for significant student input by leaving parts of the syllabus incomplete, allowing students to select, for instance, the empirical case studies of movement activity they wish to examine. This could also help students engage with theory more critically. For example, asking them to select one 'progressive' and one 'reactionary' movement and then helping them to work out the meaning of these concepts inductively from their case studies, is one way to disrupt taken-for-granted categorisations and to encourage students to generate their own knowledge claims. One last potential benefit of permitting students to select topics is that we as teachers will have to embark on the same learning journey as our students, thus mitigating the power/knowledge hierarchy that separates us from them.

Moving on to the methods we use in our teaching, feminist activist education pushes us to rethink the three conventions we identified in the first part of the article. First, it demands that we question the privileging of the text by incorporating much more thoroughly than thus far multiple media as sources of knowledge and modes of knowledge transmission. For example, not only films but also magazines as used by SOF or the songs sung at the Mumbai forum could be analysed in the lecture theatre and seminar room, along with photojournalism, advertisements and the like. 
Moreover, we need to go beyond seeing students as passive consumers or textual analysts of such media by allowing them to generate their own forms of expression and to submit as coursework, for instance, a photography portfolio on a global politics theme or a collectively produced film. ${ }^{27}$ Crucially, such coursework could be assessable by external examiners if the media used were recordable and the criteria for assessment established beforehand. In addition, we want to explore the possibility of taking students out of the university setting into the cinema, performance space, gallery or social forum, with the aim of getting them to think about global politics in diverse cultural contexts and to reflect on those emotional, intuitive responses that are central to activist education but usually sidelined in academic study.

Second, paying attention to feminist activist education forces us to question our reliance on the lecture/textbook format and to challenge more fundamentally the transmission model of learning that this fosters. We remain agreed that this model is limited in terms of encouraging students to become producers of knowledge in their own right. At a minimum, we need to stop hooking lecture series to textbooks, however wide-ranging or pedagogically progressive these may be, and creatively deploy more eclectic and diverse sources of knowledge, in the ways discussed above. Having said this, our own experience as learners at women's events at the Mumbai forum - listening to Amarjeet Kaur of the NFIW, for example - reminds us that lectures can have the capacity to arouse curiosity, inspire and provoke. Indeed, we would add that the expression of political and intellectual commitments in a lecture context is one particularly effective way of capturing the attention of an audience. Of course, there is the valid fear that the hierarchy in the lecture hall between us and our students may mean that a forceful statement of our own perspectives could serve to close down, rather than open up, debate among students eager to please and focused on exam results. Arundhati Roy offers us one strategy here: expressing a view in a way that is direct and personal but does not harangue the audience, and withdrawing from centre stage at key moments to give space to others. With respect to our lectures, this could mean sharing the podium with students or non-academics with relevant experience on a topic or particular political agendas, or with colleagues who have very different commitments to our own.

Third, turning to seminar-based teaching, feminist activist education inspires us to supplement our focus on adversarial discussion of academic texts, by introducing collective, consensual modes of constructing knowledge claims and enabling students to draw on their lived experiences, their emotional sensitivities and even their bodily reactions as sources of knowledge. We are not suggesting here the straightforward transfer to the seminar room of the testimonial form that we saw in the NFIW workshop or the DAWN research method. Rather, we suggest that these general feminist priorities encourage us to explore techniques that diversify students' understanding of where knowledge comes from and how it is created. One way of fostering curiosity about and empathy with others, for instance, is to get students to choose a political agent to represent or speak for in class discussion, whether it be the Zapatistas, Hamas, Chavez's Venezuelan government or the staff of the World Bank. Another idea is to institutionalise collaborative projects in a much more extensive way - allowing not only the small-group presentations of our current courses but also

\footnotetext{
${ }^{27}$ Several of Bice's third year students recently took the initiative to produce a short film as part of their assessed group presentation.
} 
group-written papers (a current taboo for graded coursework) and group out-of-class projects such as the design of an IR class syllabus or an aid project, or the devising of a political response to a recent conflict or World Bank policy. Such projects would require students to negotiate with each other, coming to some degree of shared understanding and agreement on strategy; students could also be pushed to reflect critically on the negotiation process, identifying what or who was left out of discussion and the power dynamics behind particular choices. Finally, we need to experiment with ways of encouraging students to talk more openly about their emotional reactions to what they are studying and how they are going about it. Rather than confining our questions to what students agree or disagree with, then, we need to ask what upsets or excites them about certain topics, what annoys or inspires them about the ways in which they are assessed. The hope is that students will become more reflective about their own political and intellectual responses and more curious about the feelings and commitments of the political agents that they study.

Last but not least, a few words are needed about our role as teachers and how we might alter our current proclivity to adopt either the umpire or facilitator approach. Speaking generally, we think that many of the feminist educational activities described above, from Arundhati Roy's speech to the Grail workshop on globalisation, challenge the power/knowledge hierarchy between teacher and student by directing us to conceive of ourselves as part of a community of learners, or as on the same learning journey as our students. As more experienced members of that community, or as further along that learning journey, we also need to face up to the degree of influence and power we have over the students. We suggest that a constructive way to do so would be to think of our role as that of a 'guide' or 'mentor'. This shift of positioning from umpire to mentor would require, in our view, that we are far more explicit about where we have come from, where we are now, and what we are trying to achieve with our classes. It would mean that we have to expose ourselves as 'one of them': as students of IR with theoretical preferences and citizens with political commitments. Moreover, it would mean we have to be more open to learning from our own students. We have already made the point that that it is possible to incorporate student recommendations for class topics; another method would be to present our own work-in-progress for student feedback. Although our ideas about the 'guide' or 'mentor' role remain as yet rather general, we wish to defend the imperative behind them, that is, that feminist activists require us to reconsider not only what we teach and how we teach it, but also how we think of ourselves as educators and what this means for our relationship to our students.

\section{Conclusion}

We began this article by pointing to the common assumption that there is a sharp division between activism and academia. This assumption is reliant on problematic dichotomies and serves to diminish both worlds. As feminists working in British universities, we have sought to find ways of bridging activism and academia through what we have termed 'critical' scholarship and pedagogy. We have explored here one possible bridge in terms of the insights that feminist 'anti-globalisation' activism can offer for our teaching on global politics. We have argued that, for feminist activists, knowledge about global politics is generated from everyday lived experiences and mediated through emotions, the body and empathetic interrelationships. Furthermore, knowledge is transmitted in creative ways using multiple media. Finally, feminist 
activists entreat us to adopt a more holistic, situated view of both the learner and the teacher as feeling, embodied, social individuals who create knowledge collectively. In our view, taking such insights seriously requires us to reach beyond our current 'add and stir' approach to the IR curriculum, the lecture theatre and seminar room and to structure our courses around an alternative, feminist framing of the nature and location of global politics and political subjectivity. It also implies treating nonacademic voices and students' own experiences as authoritative sources of knowledge and making more extensive use of multiple media. We need to think about lectures as opportunities to provoke political and intellectual curiosity while continuing to find ways to undermine the lecturer-student hierarchy. And we also need to encourage our students to learn collectively and consensually as well as individually and interrogatively, in a seminar context where we position ourselves as guides or mentors in the same learning community.

To be clear, we are not arguing here for a wholesale replacement of academic education with the activist model and we would certainly not deny that there remain some significant tensions between the two sets of imperatives. For example, we want to stress that we think it remains crucial to the academic enterprise to protect the freedom of thought of our individual students and that we want to see this combined with, rather than jeopardised by, an emphasis on collective knowledge production, consensus-building and a more explicit acknowledgement of our own political commitments. Precisely how to do this can only be worked out through careful experimentation and dialogue with our colleagues and students.

Nonetheless, we assert that expanding our understanding of the goals and ethos of academic education to include activist values is not only possible, but also potentially highly fruitful. Most obviously, in our view, the core academic goal of facilitating students to be critical thinkers would be enhanced rather than undermined by the approach described here. The examples of feminist activist education we have explored point to a more expansive, open-ended, complex and challenging view of what constitutes global politics and knowledge about it, and to a set of strategies that centre on encouraging students to see themselves as producers of knowledge about the world. Moreover, and here is where we move furthest from academic convention, feminist activist education reminds those of us committed to critical scholarship that one of our key duties is to empower our students by enabling them to see themselves as subjects of politics or political agents. This is not to say that we should be using the university to train ready-to-go activists - that remains the prerogative of activist education undertaken outside of the university context for strategic ends. It is to say that teaching global politics in a university can and in fact should be about helping students become thoughtful, reflective participants in our society; igniting their curiosity about the world and their place within it; raising their consciousness and stoking their indignation about injustice; and infusing them with a belief that they can remake their world if they wish to do so.

There are significant challenges to pursuing this feminist ethos and implementing the accompanying strategies. Certainly the entrenched commitment in British universities to the exam/essay format in assessment and the largely unquestioned faith in 'objective' standards of knowledge will make altering assessment methods an uphill battle. We also recognise that some academics have more autonomy and capacity than others to integrate these kinds of innovations into their teaching. One possible way to 
address this problem is to be more supportive of the efforts of junior colleagues to experiment with their classes. Another is to join or develop networks amongst those of us interested in critical scholarship and critical pedagogy. ${ }^{28}$ Still, recent structural developments that serve to constrain and even devalue the teaching component of the academic job mean that our task remains daunting. We would point here to the context of rising student numbers, the repositioning of students as consumers, growing administrative burdens, along with increasing pressure to produce ostensibly top quality research outputs and to secure funding to enable us to do that - all of which means that teaching, for many of us, has become at best an add-on and at worst a burden. We will need patience, persistence and a degree of courage as we try to develop and implement even a handful of the pedagogical principles and practices that have been discussed in this article. We will also need to explore other avenues through which activism can be brought into academia if the restructuring of university life, including the marginalisation of teaching, is to be contested.

\footnotetext{
${ }^{28}$ See, for example, Eric Herring's discussion of the establishment of NASPIR in this special section. Catherine participated in a series of workshops in 2004 organised by Sian Sullivan, then of the Centre for the Study of Globalisation and Regionalisation at Warwick University, aimed at developing activist/academic crossover in terms of ideas, reading and support. Sian has also been involved in the 'Radical Theory Forum' initiative; see her 'Radical Theory Workshop @ the $2^{\text {nd }}$ European Social Forum: Some Notes', online at http://www.euromovements.info/html/sian-radicaltheory.htm.
} 